\title{
Evaluation of Depression Symptoms in Students of Dental Medicine
}

\author{
Dewi Natasya Irawan ${ }^{1}$, Aryo Dwipo Kusumo ${ }^{2,3}$, Muhammad Canino Cahya C. ${ }^{1}$, \\ Nur Nandini Wirawan ${ }^{1}$, Hashfi Hilman ${ }^{1}$, Disti Ayulita ${ }^{1}$ \\ ${ }^{1}$ Undergraduate Student, Faculty of Dental Medicine, Universitas Airlangga, ${ }^{2}$ Graduate Student of Health \\ Administration and Policy, Faculty of Public Health, Universitas Airlangga, ${ }^{3}$ Department of Dental Public Health, \\ Faculty of Dental Medicine, Universitas Airlangga
}

\begin{abstract}
Background: Mental illness that is often found in daily life is depression. Not many people know that depression is a medical condition with real symptoms. Many factors can trigger psychological illnesses among students such as adjustment to the new school environment, information overload, lack of free time, financial issues, family-related issues and the competition for higher grades.
\end{abstract}

Purpose: The authors are interested in discussing the evaluation of depressive symptoms among Universitas Airlangga Faculty of Dental Medicine students.

Method: The research design that will be used in this research is descriptive with a research instrument in the form of a questionnaire. The author chose this method because the author want to know the prevalence of students with major depressive disorder in Universitas Airlangga Faculty of Dental Medicine.

Result: The results of this study shows that $34 \%$ were in normal condition, $21 \%$ experienced mild mood disorders, $11 \%$ experienced borderline clinical depression, $28 \%$ experienced moderate depression and as many as $6 \%$ experienced severe depression.

Conclusion: Based on the results of the study, it can be concluded that the majority of Universitas Airlangga Faculty of Dental Medicine students experience mild mood disorders or mild depression.

Keyword: Evaluation, Depressive Symptomps, Dental Medicine Students, Sociodemographic.

\section{Introduction}

Human in the world must have felt sick. Sick is a condition when someone's health is disturbed. When

\section{Corresponding Author:}

\section{Aryo Dwipo Kusumo}

Graduate Student of Health Administration and Policy, Faculty of Public Health, Universitas Airlanggaand Department of Dental Public Health, Faculty of Dental Medicine, Universitas Airlangga, Prof. Dr. Moestopo Street No. 47

Phone Numbers: (+6231) 5030255, 5020256, Facsimile Numbers: $(+6231) 5020256$

e-mail: kusumoaryo.450@gmail.com humans are not in a good condition, humans will be easily infected with a disease. Diseases are divided into 2 types, namely diseases that can be seen and diseases that are not visible to the eye. Visible diseases are common in daily lives, for example, cough, flu, measles, dengue fever, and so on. Different from the visible diseases, diseases that cant be seen was hard to detect, because the patient did not show a specific clinical symptoms. An example of this invisible disease is a mental illness ${ }^{1}$.

Mental health affects the way humans feel, think, and carry out daily activities. Mental health and physical health affect each other. Therefore, like physical health, mental health is also very important ${ }^{2}$.But today, the public awareness of on mental illness is still relatively low as seen from the results of the Basic Health 
Research in 2018 which shows the prevalence of mental emotional disorders in adolescents over 15 years old at 9.8 percent $^{3}$. This figure increased compared to 2013 which was 6 percent ${ }^{4}$.

The most common mental illness that is often found in daily life is depression ${ }^{5}$. Not many people know that depression is a medical condition with obvious symptoms. A lot of stigma has been circulating so far but only a few know about the truth. Those who are struggling with depression are sometimes questioned by those around them.

Mental health also affects the ability to learn and achieve maximum professional potential. Depression is a mental health condition that is often found and affects the majority of health care students 6,7 . Dentistry schools are known to have a very demanding and stressful learning environment that often results in medical condition such as depression, obsessive-compulsive disorder, psychosomatic activity related to stress and increased mood disorders, and excessive interpersonal sensitivity ${ }^{8}$.

There are many factors that can trigger psychological illnesses among students such as adjustment to the new school environment, information overload, lack of free time, financial issues, family-related issues and the competition for higher grades. Therefore, with this paper, the author wants to know the prevalence of major depressive disorder in Universitas Airlangga Faculty of Dental Medicine students. Thus, the purpose of the writing of this paper is to determine the level of depressive symptoms in preclinical students of the Faculty of Dental Medicine, Universitas Airlangga.

\section{Research Method}

The research design that will be used in this research is descriptive study. The author chose this method because the author wants to know the prevalence of major depressive disorder in Universitas Airlangga, Faculty of Dental Medicine students. This research was conducted in the area of the Faculty of Dental Medicine, Universitas Airlangga. Researchers chose this location because based on observations that shows the awareness of the Dental Medicine of Universitas Airlangga community on mental health is still relatively low. Researchers chose the location with the aim of wanting to know the prevalence of major depressive disorder in the Faculty of Dental Medicine, Universitas Airlangga. The population in this study were students of the Faculty of Dental Medicine who were educated at Universitas Airlangga in 2019.Sampling is based on pre-clinic students who are randomly assigned to each school year with a total of 100 samples.

Table 1. Research Variable

\begin{tabular}{|c|c|c|}
\hline Variable & Operational Definition & Category and Criteria \\
\hline \multirow{15}{*}{$\begin{array}{l}\text { Students of Dental Medicine of } \\
\text { University of Airlangga (Independent } \\
\text { Variable) }\end{array}$} & 2016 & \multirow{4}{*}{ Class of } \\
\hline & 2017 & \\
\hline & 2018 & \\
\hline & 2019 & \\
\hline & 16 years old & \multirow{7}{*}{ Age } \\
\hline & 17 years old & \\
\hline & 18 years old & \\
\hline & 19 years old & \\
\hline & 20 years old & \\
\hline & 21 years old & \\
\hline & 22 years old & \\
\hline & Surabaya & \multirow{2}{*}{ Home Address } \\
\hline & Outisde of Surabaya & \\
\hline & Women & \multirow{2}{*}{ Sex } \\
\hline & Men & \\
\hline
\end{tabular}




\begin{tabular}{|l|l|c|}
\hline Variable & Operational Definition & Category and Criteria \\
\hline \multirow{4}{*}{$\begin{array}{l}\text { Depressive Symptomps } \\
\text { (Dependent Variable) }\end{array}$} & Range of Values from 0-10 & Normal \\
\cline { 2 - 3 } & Range of Values from 11-16 mood disorder \\
\cline { 2 - 3 } & Range of Values from 17-20 & Borderline clinical depression \\
\cline { 2 - 3 } & Range of Values from 21-30 & Moderate depression \\
\cline { 2 - 3 } & Range of Values from 31-40 & Severe depression \\
\cline { 2 - 3 } & Range of Values over 40 & Extreme depression \\
\hline
\end{tabular}

The research data is collected by filling out the Beck Depression Inventory questionnaire.After all data from the BDI questionnaire is obtained, the number of questionnaire values is calculated. The range of values 0-10 indicates minimal depression (no depression), 1116 indicates mild mood disorder, 17-20 shows borderline clinical depression, 21-30 shows moderate depression, 31-40 indicates severe depression, and more than 40 indicates extreme depression.

\section{Results}

In the study conducted using a questionnaire survey of 100 random samples in preclinical students of the Faculty of Dental Medicine, Universitas Airlangga.

From the results of the research that have been conducted, from 100 samples of random preclinical students of the Faculty of Dental Medicine, Universitas Airlangga, it was found that as many as $34 \%$ of the study samples did not suffer from any depressive symptoms, $21 \%$ of the study samples suffered a mild mood disorders, $11 \%$ suffered borderline depression, $28 \%$ moderate depression, and $6 \%$ of the study sample suffered severe depression.

\section{Table 2. Result of the Research}

\begin{tabular}{|l|c|c|}
\hline Depressive Symptomps & Total & Percentage \\
\hline Normal & 34 & $34 \%$ \\
\hline Mild Mood Disorder & 21 & $21 \%$ \\
\hline Borderline Depression & 11 & $11 \%$ \\
\hline Moderate Depression & 28 & $28 \%$ \\
\hline Severe Depression & 6 & $6 \%$ \\
\hline
\end{tabular}

Table 3. Result of the Research based on Variables

\begin{tabular}{|c|c|c|c|c|c|}
\hline Variable & Normal & $\begin{array}{l}\text { Mild Mood } \\
\text { Disorder }\end{array}$ & $\begin{array}{l}\text { Borderline } \\
\text { Depression }\end{array}$ & $\begin{array}{l}\text { Moderate } \\
\text { Depression }\end{array}$ & Severe Depression \\
\hline \multicolumn{6}{|l|}{ Class of } \\
\hline 2016 & 9 & 3 & 6 & 11 & 1 \\
\hline 2017 & 6 & 6 & 0 & 6 & 3 \\
\hline 2018 & 3 & 4 & 2 & 5 & 2 \\
\hline 2019 & 16 & 8 & 3 & 6 & 0 \\
\hline \multicolumn{6}{|l|}{ Age } \\
\hline 16 year old & 0 & 1 & 0 & 0 & 0 \\
\hline 17 year old & 2 & 0 & 1 & 0 & 0 \\
\hline 18 year old & 12 & 6 & 1 & 6 & 1 \\
\hline 19 year old & 3 & 6 & 3 & 5 & 3 \\
\hline 20 year old & 10 & 4 & 0 & 6 & 1 \\
\hline 21 year old & 3 & 2 & 6 & 9 & 0 \\
\hline 22 year old & 4 & 2 & 0 & 2 & 1 \\
\hline
\end{tabular}




\begin{tabular}{|c|c|c|c|c|c|}
\hline Variable & Normal & $\begin{array}{l}\text { Mild Mood } \\
\text { Disorder }\end{array}$ & $\begin{array}{l}\text { Borderline } \\
\text { Depression }\end{array}$ & $\begin{array}{c}\text { Moderate } \\
\text { Depression }\end{array}$ & Severe Depression \\
\hline \multicolumn{6}{|l|}{ Sex } \\
\hline Men & 6 & 5 & 2 & 7 & 3 \\
\hline Women & 28 & 16 & 9 & 21 & 3 \\
\hline \multicolumn{6}{|l|}{ Home Address } \\
\hline Surabaya & 12 & 7 & 3 & 8 & 1 \\
\hline Outside of Surabaya & 22 & 14 & 8 & 20 & 5 \\
\hline
\end{tabular}

\section{Discussion}

The results of this study indicate that among 100 students studying at the Faculty of Dental Medicine, Universitas Airlangga, 30 students in the class of 2016 students 9 was normal, 3 students suffered from mild mood disorder, 6 students with borderline depression, 11 students with moderate depression, and 1 student with severe depression. The results of this study indicate that depression among students in the class of 2016 is more on the moderate type.

Then, in 21 students in the class of 2017, 6 was normal, while 6 students suffered from mild mood disorder, 6 students with moderate depression, and 3 students with severe depression. These results indicate that depression among students class of 2017 is more in the moderate type, mild mood disorders, and normal. In class of 20183 students was normal, 4 students suffered from mild mood disorder, 2 students with borderline depression, 5 students with moderate depression, and 2 students with severe depression. These results indicate that depression among students in the class of 2018 is more in the moderate depression.

Then, in the class of 201916 students was normal, 8 students suffered from mild mood disorder, 3 students with borderline depression, and 6 students with moderate depression. These results indicate that depression in students in the class of 2019 falls into the normal category.

From the results of this study it can be concluded that in the class of 2018 and 2016 more students experienced symptoms of moderate depression than with other class. This can be caused because students are on a temporary transition period from adolescence into adulthood and can be the most stressful time in a person's life. The process of adapting into the environment on campus, maintaining good grades, thinking about the future, and being away from home are often the cause of anxiety for most students so that they will end up suffering depression ${ }^{9}$.

From the age variable, the results of this study indicate that among 100 students studying at the Faculty of Dental Medicine, Universitas Airlangga, 1 student who was 16 years old suffered mild mood disorder. Then, 3 students aged 17 years 2 of them was normal while the other one suffer a moderate depression. These results indicate that depression among 17-year-old students is more in the normal. Then in 26 students aged 18 year there were 12 students that was normal, 6 students suffered a mild mood disorder, 1 student with borderline depression, 6 students with moderate depression, and 1 student with severe depression. These results indicate that depression among students aged 18 years is more in the normal type.

In 20 students aged 19 years there were 3 students that was normal, 6 students suffered from mild mood disorder, 3 students with borderline depression, 5 students with moderate depression, and 3 students with severe depression. These results indicate that depression among 19-year-old students is more in the mild mood disorder. Then in 21 students aged 20 years there were 10 that was normal, 4 students with mild mood disorder, 6 students with moderate depression, and 1 student with severe depression. These results indicate that depression among students aged 20 years is more in the normal type.

In 20 students aged 21 years there were 3 students that was normal, 2 students with mild mood disorder, 6 students with borderline depression, and 9 students with moderate depression. These results indicate that depression among 21-year-old students is more in the moderate depression. Then, in 9 students aged 22 years there were 4 students that was normal, 2 students with mild mood disorder, 2 students with moderate depression, and 1 student with severe depression. These 
results indicate that depression among students aged 22 years is more in the normal type.

In the research results above it is known that students in the 16-22 age category are young adult age categories ${ }^{10}$. According to the journal it is said that young adults are a transition phase that experiences new challenges, roles and tasks for some individuals. Risk factors for mental disorders in this phase can be influenced by low social life. Mental disorders may make it difficult to transition from adolescence to adulthood so that it will become depressed. This depression can cause distress to an individual in the school environment and in the formation of social relations. Social life is associated with better mental health and is the most influential factor being young adulthood. Detection of depression in young adults becomes very important to get better treatment results and to improve the long-term prognosis of people who initially experience symptoms of depression ${ }^{10}$.

In the gender variable, the results of this study indicate that among the 100 students studying at the Faculty of Dental Medicine, Universitas Airlangga, of the 23 male students there were 6 students that was normal, 5 students with mild mood disorder, 2 students with borderline depression, 7 students with moderate depression, and 3 students with severe depression. The results of this study indicate that depression among male students is more in the moderate depression. Whereas in 77 female students there were 28 students that was normal, 16 students with mild mood disorder, 9 students with borderline depression, 21 students with moderate depression, and 3 students with severe depression. The results of this study indicate that depression among female students is more in the normal type.

From the result it is known that male students are more in the moderate depression while in female students are more in the normal type and moderate depression. Some study found that the highest risk of depression is in women ${ }^{11,12}$. This may be due to the biological conditions of sex differences and have no influence on race, food, education, and various social and economic factors $^{13-15}$. In this journal it was found that depression suffered twice in young adult women than men (aged 14-25 years), but this ratio declined with increasing age $^{16}$. In fact when entering the puberty phase, young adult women are at the greatest risk for experiencing severe depression and mental disorders. The increase in the prevalence of depression can be related to hormonal changes in women, especially during puberty, before menstruation, after pregnancy and during the menopause phase, suggesting that fluctuations in female hormones can be a trigger for depression ${ }^{2,11}$.

In the original variable, the results of this study indicate that among 100 students studying at the Faculty of Dental Medicine of Universitas Airlangga, of the 31 students from Surabaya there were 12 students that was normal, 7 students with mild mood disorder, 3 students with borderline depression, 8 students with moderate depression, and 1 student with severe depression. The results of this study indicate that depression among students who come from Surabaya is more in the normal type. Whereas 69 students from outside Surabaya assumed that all samples in this variable were overseas students, there were 22 students that was normal, 14 students with mild mood disorder, 8 students with borderline depression, 20 students with moderate depression, and 5 students with severe depression.

The results of this study indicate that depression among students who come from outside Surabaya is more in the normal type. In the results of the above study it is known that the origin of the sample does not greatly affect a person's level of depression ${ }^{17}$. This is because the prevalence of depression of students from Surabaya and outside Surabaya shows the same results, namely the highest prevalence in the normal category.

\section{Conclusion}

Based on the results of the study, it can be concluded that $34 \%$ of Universitas Airlangga Faculty of Dental Medicine students do not suffer from major depressive disorder, but $66 \%$ of Universitas Airlangga Faculty of Dental Medicine students suffer from depression with varying degrees of severity namely mild mood disorders, borderline depression, moderate depression, to severe depression.

Based on this study, the authors suggest to the general public, especially the academic community of the Faculty of Dental Medicine, Universitas Airlangga to improve their knowledge about depression symptoms. This is to prevent excessive mental burden so that it cant endanger the students themselves.

Conflicts of Interest: There are no conflicts of interest.

Source of Funding: Self-Funding 
Ethical Clearance: Approved

\section{References}

1. Michael KD, Hueisman TJ, Gerard C, Gilligan TM, Gustafson MR. Depression among college students: Trends in prevalence and treatment seeking. Couns Clin Psychol J. 2006;3(2):60-70.

2. Beiter R, Nash R, Mccrady M, Rhoades D, Linscomb M, Clarahan M, et al. The prevalence and correlates of depression, anxiety, and stress in a sample of college students. J Affect Disord. 2015;173:90-96.

3. Ministry of Health of the Republic of Indonesia. Riset Kesehatan Dasar (Riskesdas) Tahun 2018. Jakarta; 2018.

4. Ministry of Health of the Republic of Indonesia. Riset Kesehatan Dasar (Riskesdas) Tahun 2013. Jakarta; 2013.

5. Ikram, K., Leghari, M. A., Khalil, S., Kainat R. Prevalence of Symptoms of Depression among the Dental Undergraduates, Karachi, Pakistan. Int Dent Med J Adv Res. 2018;2:175-178.

6. Martasari, O. D., Ediati A. Harapan Orangtua Dan Depresi Pada Mahasiswa Program Studi S1 Kedokteran Umum . J Empati. 2018;7(3):1-8.

7. Pratiwi PS, Lesmana CBJ. Hubungan antara cemas dan depresi mahasiswa kedokteran Universitas Udayana dengan keinginan dan harapan dari karir kedokteran. E- J Med. 2016;5(5):1-8.

8. Basudan, Sumaya, Binanzan, Najla, Alhassan A. Depression, anxiety and stress in dental students. Int J Med Educ. 2017;8:179-86.

9. Sarokhani D, Delpisheh A, Veisani Y, Sarokhani MT, Manesh RE, Sayehmiri K. Prevalence of Depression among University Students: A Systematic Review and Meta-Analysis Study. Depress Res Treat. 2013;373857.

10. Barth J, Hofmann K, Schori D. Depression in early adulthood: Prevalence and psychosocial correlates among young Swiss men. Swiss Med Wkly. 2014;144(April):1-8.

11. Albert PR. Why is depression more prevalent in women? J psychiatry Neurosci. 2015;40(4):219221.

12. Darmayanti N. Meta-Analisis : Gender Dan Depresi Pada Remaja. J Psikol. 2015;35(2):164-180.

13. Hardjosoesanto, A.Y., AS, W.S., Jusup I. Hubungan antara Tingkat Depresi dengan Tingkat Sugestibilitas pada Mahasiswa Fakultas Kedokteran Tahun Pertama. JKD. 2017;6(2):288-96.

14. Thurai, S. R. T., Westa W. Tingkat Depresi dalam Kalangan Mahasiswa Kedokteran Semester VII Universitas Udayana dan Keterlibatan Mereka dalam Kegiatan Fisik. Intisari Sains Medis. 2017; 8(2):147-50.

15. Haryanto., Wahyuningsih HD, Nandiroh S. Sistem Deteksi Gangguan Depresi Pada Anak-Anak Dan Remaja. J Ilm Tek Ind. 2015;14(2):142-52.

16. Aryadi IPH, Yusari IGAAA, Dhyani IDAD, E. KIP, Sudira PG. Korelasi kualitas tidur terhadap tingkat depresi cemas, dan stres mahasiswa kedokteran Universitas Udayana. Callosum Neurol. 2018;1(1):10-15.

17. Christyanti D, Mustami'ah D, Sulistiani W. Hubungan antara penyesuaian diri terhadap tuntutan akademik dengan kecenderungan stres pada mahasiswa Fakultas Kedokteran Universitas Hang Tuah Surabaya. Insan. 2010;12(3):153-9. 